\title{
Arbuscular mycorrhizal fungal diversity in wheat agro- ecosystems in Southern Chile and effects of seed treatment with natural products
}

\author{
Claudia G. Castillo ${ }^{1,2 *}$, Fritz Oehl ${ }^{3,4}$, Ewald Sieverding ${ }^{5}$ \\ ${ }^{1}$ Escuela de Agronomía, Facultad de Recursos Naturales, Universidad Católica de Temuco, Temuco, Chile. \\ ${ }^{2}$ Núcleo de Investigación en Producción Alimentaria. UC Temuco. Corresponding author: ccastill@uct.cl. \\ ${ }^{3}$ Agroscope, Ecotoxicology, Schloss 1, CH-8820, Wadenswil, Switzerland.fritz.oehl@agroscope.admin.ch. \\ ${ }^{4}$ Departamento de Micologia, Universidade Federal de Pernambuco, Avenida da Engenharia s/n, CEP 50740- \\ 600, Recife, Brazil.fritz.oehl@agroscope.admin.ch. ${ }^{5}$ University Hohenheim, Institute of Plant Production and \\ Agro-ecology in the Tropics and Subtropics, Stuttgart, Germany.
}

\begin{abstract}
Arbuscular mycorrhizal (AM) fungi are important for P uptake in Andisols cultivated with wheat. We assessed AM fungal diversity in field experiments established with wheat cultivated after AM host plants and non-host plants at three locations of the Araucanía Region. Wheat seed was treated with two natural products: Fosfobio (FOS), mixture of P-solubilizing bacteria and $\mathrm{N}_{2}$-fixing bacteria; and Myconate (MYC), product containing formononetin. For investigations of AM fungal diversity, soil samples were taken before planting and after harvest of wheat. The morphological spore analyses resulted in 26 species, belonging to 10 families and 16 genera; 5 species belonged to Acaulospora (31.2\% of total), and 3 to Claroideoglomus (18.8\%). Claroideoglomus claroideum was the prevalent while Ambispora leptoticha, Dominikia aurea, and Glomus badium presented the lowest frequency. The AM fungal species distribution was strongly dependent on the location, and richness at planting of wheat was higher when a non-host for AM fungi had been grown before. There appeared to be a tendency that through wheat cultivation, the richness of AM fungal species decreased from time of planting to harvest when the pre-crop was a non-host; when the pre-crop was AM host there was no apparent decrease in AM species richness through wheat cultivation. Natural products did not significantly influence grain yields. However, there was a tendency that MYC increased average grain yields by $7 \%$. It is discussed that increased AM root colonization, as by MYC and improved P-uptake by AM fungi is more important than inoculation of seed with P-solubilizing microbes.
\end{abstract}

Keywords: Crop rotation, host plants, natural products, species richness 


\section{Introduction}

Southern Chile has the country's main cereals producing area. Wheat is planted on around 106,790 ha, contributing some $41.6 \%$ of Chile's total wheat production (Larraín and Olfos, 2013). The Andisols in the area are low in available nutrients and phosphorus (P) deficiency can limit wheat production (Pino et al., 2002). Several studies from the area have shown that most crops depend on arbuscular mycorrhizal (AM) fungi for growth in these Andisols (Borie et al., 2010). Wheat roots, too, are symbiotically associated with AM fungi, as is known since long time. It has been postulated that management of indigenous AM fungi may be a valuable agronomic tool for optimising $\mathrm{P}$ acquisition in cereals by biological means, thus increasing soil productivity and grain yields (Sieverding, 1991). Of all the factors influencing AM fungal community dynamics and associations with plants, agricultural practices can be considered to be the most important (Barea, 2015). Soil management, such as the intensity of cultivation, the quality and quantity of herbicides applied and the plant protection strategies used can have severe impacts on AM fungal activity and community structure (Jansa et al., 2003). Tillage and fallow periods, crop rotation sequences - including alternating host with non-host plants - have been reported as other critical factors affecting the diversity of AM fungi (Harinikumar and Bagyaraj, 1988). Oehl et al. $(2003$; 2005) reported that increased land use intensity was correlated with a decrease in AM fungal species richness and with preferential occurrence and selections of species in agro-ecosystems in Central Europe. Also, Miranda et al. (2005) confirmed that the species richness of AM fungi is influenced by the associated crop and the type of soil management.

Information about the species composition of the AM fungal community appears important for understanding mycorrhizal function in ecosystems. In agro-eco- systems of the La Araucanía Region of Chile, most research into AM fungi has been focused on determining plant responses to symbiosis, regardless of the origin or identity of the AM fungi. In general terms, there is little information on the identity of AM fungi associated with wheat in the region. Only two studies are known: Castillo et al. (2006) reported the diversity of fungal species in a crop rotation of oats with wheat, cropped under conventional tillage and non-tillage, and Aguilera et al. (2014) reported on the diversity of AM fungi in different wheat varieties tolerant to higher aluminium concentrations in soils.

The addition of natural products (NP) to the soil is an alternative agronomic practice that can stimulate root development (Siqueira et al., 2002), causing increased susceptibility to colonization by AM fungi and improving recognition between the root and AM fungi (Sarabia-Ochoa et al., 2010). Natural products are complex mixtures of ingredients that may include organic acids, plant extracts, hormones or microorganisms. One NP, formononetin is an isoflavon that is extracted from clover roots. Some 20 years ago it was found to improve early AM infection of plants (Baroja et al., 2010) and recently also of wheat (Castillo et al., 2016a). This active principle showed quite consistent improvements in root mycorrhization and improvement of yields (Westphal et al., 2008), and has been reported to enhance AM fungal sporulation (Siqueira et al., 1991; Davies et al., 2005). Other NP containing free-living soil bacteria can release phosphate ions that are then captured by AM fungal hyphae for the host plant (Bonfante and Anca, 2009; Azcón-Aguilar and Barea, 2015). One of these is Fosfobio (FOS), a NP formed by a mixture of three phosphorus-solubilizing bacteria.

Given the importance associated to mycorrhizal fungal diversity for maintaining the functioning of 
ecosystems, a better understanding of the influence of land-use and agricultural practices on AM fungal diversity is needed (Soka and Ritchie, 2015). Therefore, the objective of the research presented here was to investigate whether selected natural products affect AM fungal richness and diversity in the rhizosphere of wheat that grew after host plants (oats) and nonhost plants (lupine and oil seed rape) in three locations of the Araucanía Region, and to determine the species richness of AM fungal in these agro-ecosystems. Our hypothesis was that non-host pre-crops will decrease AM fungal diversity in the field and that only by means of NP a higher AM fungal diversity can be obtained in wheat mono-culturing.

\section{Materials and Methods}

One year experiments with wheat (Triticum aestivum L.) were carried out in three different lo- calities in the Araucanía Region: a) El Carmen (Car), where AM non-host lupine (Lupinus albus L.) had been grown, $\left(\mathrm{Car}_{\mathrm{LW}}\right)$; b) Huichahue (Hui), where the AM-host oats (Avena sativa L.) had been grown ( $\mathrm{Hui}_{\mathrm{OW}}$ ) and c) Vilcún (Vil), where in one site the AM non-host oilseed rape (Brassica napus L.) ( $\left.\mathrm{Vil}_{\mathrm{RW}}\right)$, had been grown, and at other site the AM-host oats ( Vil ${ }_{\text {ow }}$ ).

At all locations, the fields were in fallow and covered with mixed pasture grasses and forbs before planting wheat in the experiments. When the study commenced, these fallow plants were ploughed under. The Huichahue soil differed from the others through higher organic matter and available soil phosphate content (Table 1).

Table 1. Geographical location and chemical properties of soils of wheat agro-ecosystems used in this study.

\begin{tabular}{|c|c|c|c|c|c|c|}
\hline Locality & Location & $\begin{array}{c}\text { Soil } \\
\text { Order }\end{array}$ & Crop rotation & $\mathbf{p H} \mathbf{H}^{\mathrm{A}}$ & OM $(\%)^{B}$ & $\begin{array}{r}\text { Available P } \\
\left(\mathrm{mg} \mathrm{kg}^{-1}\right)^{\mathrm{C}}\end{array}$ \\
\hline El Carmen & $\begin{array}{l}38^{\circ} 43^{\prime} \mathrm{S} ; \\
72^{\circ} 43^{\prime} \mathrm{W}\end{array}$ & Ultisol & Lupine-wheat & 5.3 & 6 & 4 \\
\hline Huichahue & $\begin{array}{l}38^{\circ} 50^{\prime} \mathrm{S} ; \\
72^{\circ} 31^{\prime} \mathrm{W}\end{array}$ & Andisol & Oats-wheat & 5.4 & 16 & 14 \\
\hline Vilcún & $\begin{array}{l}38^{\circ} 15^{\prime} \mathrm{S} ; \\
72^{\circ} 50^{\prime} \mathrm{W}\end{array}$ & Andisol & $\begin{array}{c}\text { Oilseed rape- } \\
\text { wheat }\end{array}$ & 5.5 & 7 & 5 \\
\hline Vilcún & $\begin{array}{l}38^{\circ} 39^{\prime} \mathrm{S} ; \\
72^{\circ} 03^{\prime} \mathrm{W}\end{array}$ & Andisol & Oats-wheat & 6.1 & 8 & 6 \\
\hline
\end{tabular}

${ }^{\mathrm{A}}$ Measured in $\mathrm{H}_{2} \mathrm{O}$; ${ }^{\mathrm{B}}$ Walkley and Black method; ${ }^{\mathrm{C}}$ Extractable by Olsen method (Zagal and Sadzawka, 2007). 
In El Carmen and Huichahue, experiments were established in October 2011 and the wheat was harvested in February 2012. Wheat var. "Otto-Baer" was planted at seed dose equivalent to $200 \mathrm{~kg} \mathrm{ha}^{-1}$. Seed had been treated with the fungicide DIVIDEND 030 FS (30 $\mathrm{g} \mathrm{L}^{-1}$ difenoconazole) at $150 \mathrm{~mL} 100 \mathrm{~kg} \mathrm{seed}^{-1}$. The wheat was fertilized with $333 \mathrm{~kg} \mathrm{ha}^{-1}$ of a mixture of 7-27-8-6-14 N- $\mathrm{P}_{2} \mathrm{O}_{5}-\mathrm{K}_{2} \mathrm{O}-\mathrm{S}-\mathrm{Ca}$ at sowing. All weeds were hand pulled throughout the study; the cultivated wheat was the only host plant for the AM fungi in these field plots. There was no foliar fungicide or insecticide application in these trials. At Vilcún, field trials were established in July 2012, and the wheat was harvested in February 2013. Wheat var. "Crac-Baer" was planted at $200 \mathrm{~kg} \mathrm{ha}^{-1}$. The seed had been treated with $150 \mathrm{~mL}$ DIVIDEND and $125 \mathrm{~mL}$ FORCE $3 \mathrm{G}$ ( $30 \mathrm{~g} \mathrm{~L}^{-1}$ tefluthrin). The wheat was fertilized with 333 $\mathrm{kg} \mathrm{ha}^{-1}$ of a complete fertilizer mixture of 7-27-8-6-14 $\mathrm{N}-\mathrm{P}_{2} \mathrm{O}_{5}-\mathrm{K}_{2} \mathrm{O}-\mathrm{S}-\mathrm{Ca}$ at sowing; two applications every two months followed with potassium nitrate (at $50 \mathrm{~kg}$ $\left.\mathrm{KNO}_{3} \mathrm{ha}^{-1}\right)$. The herbicide TRAXOS $\left(25 \mathrm{~g} \mathrm{~L}^{-1}\right.$ clodinafop $+25 \mathrm{~g} \mathrm{~L}^{-1}$ pinoxaden) was applied at $2.4 \mathrm{~L} \mathrm{ha}^{-1}$, to control weeds. The fungicide PRIORI $\left(200 \mathrm{~g} \mathrm{~L}^{-1}\right.$ azoxystrobin $+80 \mathrm{~g} \mathrm{~L}^{-1}$ cyproconazole) was applied at $1 \mathrm{~L} \mathrm{ha}^{-1}$ at growth stage (GS) 41 to control foliar diseases, and the insecticide ENGEO (141 $\mathrm{g} \mathrm{L}^{-1}$ of thiamethoxame $+106 \mathrm{~g} \mathrm{~L}^{-1}$ lambda-cyhalothrine) was used at $100 \mathrm{~mL} \mathrm{ha}^{-1}$ to control insects at GS 41 . For the experiments, wheat seeds were treated, either with above fungicides and/or insecticides alone (Control, $\mathrm{CON}$ ), or in addition with the two natural products:

a) Fosfobio (FOS), which is a commercial product containing a mixture of the phosphorus-solubilizing bacteria: Bacillus megaterium and Bacillus polymyxa, and Azotobacter, a genus of free-living nitrogen fixing bacteria. $100 \mathrm{~mL}$ FOS was diluted in $1 \mathrm{~L}$ water and was carefully sprayed and mixed on the equivalent of $100 \mathrm{~kg}$ seed, after the chemical seed treatment; b) Myconate ${ }^{\circledR}$ (MYC) is a product of a water-soluble potassium salt of formononetin (7-hidroxy, 4'-metoxy isoflavone). This product is not commercially available in Chile but is known to consistently improve the mycorrhizal colonization of plants. $100 \mathrm{~g}$ were dissolved in $1 \mathrm{~L}$ of water and sprayed/mixed with the equivalent of $100 \mathrm{~kg}$ seed, in an extra step after chemical seed treatment.

Plots were established at $12 \mathrm{~m}^{2}(4 \mathrm{~m} \mathrm{x} 3 \mathrm{~m})$, with four replicates per treatment with a total of 12 experimental units in a complete randomized block design. Seed was planted by hand in furrows at $3-5 \mathrm{~cm}$ depth at about 500 seeds $\mathrm{m}^{-2}$, in distance of $20 \mathrm{~cm}$ between rows.

For the investigation of the diversity of AM fungal species, representative soil samples were collected from the areas: a) before planting wheat (this means after ploughing the fallow, FAL) and $b$ ) after wheat harvest (CON, FOS, MYC). Each soil sample was a composite of eight cores $(6 \mathrm{~cm}$ diameter $\times 10 \mathrm{~cm}$ deep) and was taken from each of the four field replications. Samples were homogenized and were stored in a refrigerator before AM fungal spores extraction.

AM fungal spores were extracted from $20 \mathrm{~g}$ soil by the method of wet sieving and decanting, established by Gerdemann and Nicolson (1963). Briefly, soil was dispersed in water and the suspension was passed through sieves of 425, 53 and $32 \mu \mathrm{m}$ mash opening while thoroughly washing with water. The last soil portions collected in $32 \mu \mathrm{m}$ mesh and the soil fraction of $53 \mu \mathrm{m}$ were mixed and distributed into plastic tubes; $20 \mathrm{~mL}$ of a $70 \%$ sucrose solution were inserted at the bottom of the tubes and the mixture was centrifuged at $2500 \mathrm{rpm}$ for $7 \mathrm{~min}$. The spores were decanted after centrifugation, washed and transferred to Petri dishes. AM fungal spores were isolated and permanent preparations were made with polyvinyl alcohol in lactoglycerol 
(PVLG) and a mixture of PVLG and Melzer's reagent for species identification. The morphological properties and their subcellular structures were observed under high-power light microscopy at 100 $\times$ and $400 \times$ magnification. Subsequently, species were identified by morphological analyses of the spores, using the descriptions of AM fungal found in Schenck and Pérez (1990) and Błaszkowski (2012), http://invam.caf.wvu.edu, and latest AM fungal species descriptions.

Species richness is the easiest way to assess the diversity of species within communities. It is based on the number of species present, without considering their relative importance (Moreno, 2001), and is defined as the total number of species observed per sampling site. In this study the richness was expressed as the number of species of AM fungi in a $20 \mathrm{~g}$ soil sample.
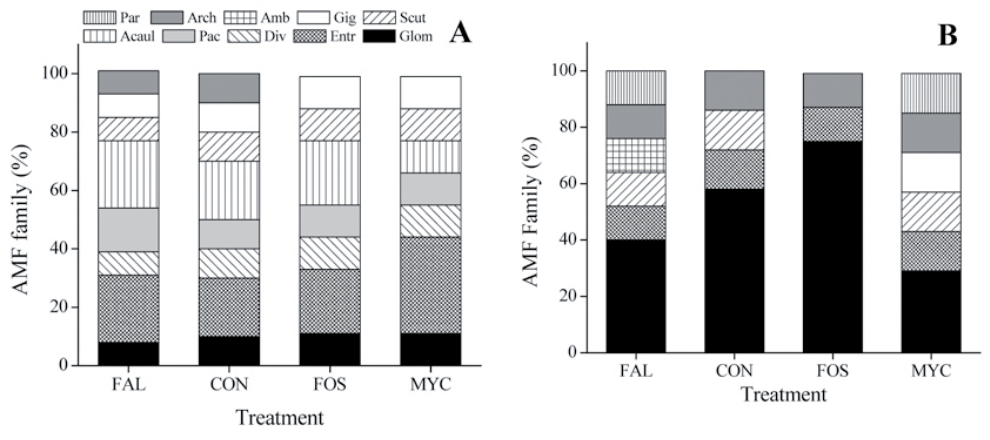

C
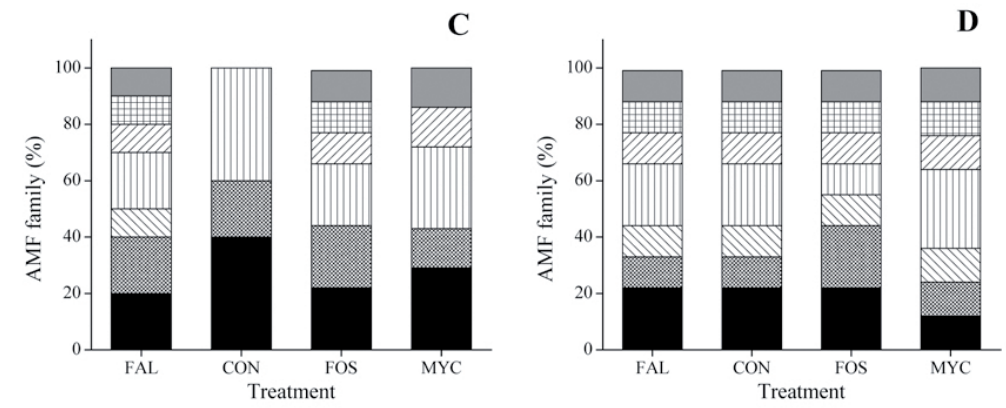

Table 2 presents the occurrence of a fungal species when found in any of the 4 replicates at a trial site.

Grain yields were taken in the experiments and yields were calculated in $\mathrm{kg}$ per ha after readjustment of grain humidity to $14 \%$. Average yields are presented. For statistical analyses of the studied variables, one-way ANOVA was performed. Means were compared by Tukey's multiple range test. Statistical significance was determined at $\mathrm{P}<0.05$. Analysis of variance was carried out with SPSS software package (version 13.0).

\section{Results}

In the research area, we recorded 26 AM fungal species in total (Table 2) that belonged to 10 families (Figure 1) and 16 genera.

Figure 1. Distribution of arbuscular mycorrhizal fungal families in wheat agro-ecosystems of the Araucanía Region: Car ${ }_{\mathrm{LW}}$ (A), Hui ${ }_{\mathrm{OW}}(\mathrm{B}), \mathrm{Vil}_{\mathrm{RW}}$ (C) and $\mathrm{Vil}_{\mathrm{OW}}$ (D) treated with natural products. FAL: fallow; CON: control; FOS: Fosfobio; MYC: Myconate; Glom:Glomeraceae; Entr:Entrophosporaceae; Div:Diversisporaceae; Pac:Pacisporaceae; Acaul:Acaulosporaceae; Scut:Scutellosporaceae; Gig:Gigasporaceae; Amb:Ambisporaceae; Arch:Archaeosporaceae; Par:Paraglomeraceae 
It was clearly visible that one location differed strongly in the presence or absence of AM fungi genera: the genera Dominikia, Paraglomus, Sclerocystis, Septoglomus and Simiglomus were only found at Huichahue while species of Acaulosporaceae and Pacisporaceae were totally lacking at this site (Figure 1, Table 2). Of the other three locations the two fields at Vilcún $\left(\mathrm{Vil}_{\mathrm{RW}}\right.$ and $\mathrm{Vil}_{\mathrm{OW}}$ ) were most similar in presence of AM fungal species (Table 2) while differing from El Carmen $\left(\mathrm{Car}_{\mathrm{LW}}\right)$ through absence of Gigaspora, a Glomus sp., and presence of e.g. Claroideoglomus lamellosum.

At locations with pre-crop lupines $\left(\mathrm{Car}_{\mathrm{LW}}\right)$ and rape $\left(\mathrm{Vil}_{\mathrm{RW}}\right)$ the total number of AMF species tended to be higher before planting of wheat than at harvest of wheat at these sites (Table 2). In these plots, wheat cultivation tended to decrease the AMF species rich- ness, whether without or with seed treatment (from 13 and 10 spp. to 9 to 10 and 5 to 9 spp. at $\mathrm{Car}_{\mathrm{LW}}$ and $\mathrm{Vil}_{\mathrm{RW}}$, respectively); the effect was significant at $\mathrm{Vil}_{\mathrm{RW}}$ in the control without NP seed treatment, only. At locations with pre-crop oats ( $\mathrm{Hui}_{\mathrm{OW}}$ and $\mathrm{Vil}_{\mathrm{OW}}$ ) no effect of wheat cultivation and of seed treatment was observed from planting to harvest ( 7 to 8 and 8 to 9 species found in all plots).

Grain yields of wheat at the experimental sites (Table 3) were higher in Vilcún than in the others two locations. While FOS had no or even slight negative effect on average yields of the four sites, MYC tended to increase yields. However, the effect of seed treatment with a natural product was statistically not significant at none of the locations.

Table 2. Arbuscular mycorrhizal fungal species in wheat agro-ecosystems treated with natural products in the Araucanía Region.

\begin{tabular}{|c|c|c|c|c|c|c|c|c|c|c|c|c|c|c|c|c|}
\hline \multirow{3}{*}{ AM fungal species* } & \multicolumn{16}{|c|}{ Wheat ecosystem } \\
\hline & \multicolumn{4}{|c|}{ Carıw } & \multicolumn{4}{|c|}{ Huiow } & \multicolumn{4}{|c|}{ Vilkw } & \multicolumn{4}{|c|}{ Vilow } \\
\hline & FAL & $\mathrm{CON}$ & FOS & MYC & FAL & $\mathrm{CON}$ & FOS & MYC & FAL & $\mathrm{CON}$ & FOS & MYC & $\begin{array}{c}\text { FA } \\
\text { L }\end{array}$ & $\mathrm{CON}$ & FOS & MYC \\
\hline \multicolumn{17}{|l|}{ Acaulospora } \\
\hline Acaulospora laevis & & & & & & & & & & $\mathrm{x}$ & $\mathrm{x}$ & $\mathrm{x}$ & & $\mathrm{x}$ & $\mathrm{x}$ & $\mathrm{x}$ \\
\hline Ac. mellea & $\mathrm{x}$ & $\mathrm{x}$ & $\mathrm{x}$ & $\mathrm{x}$ & & & & & & & & & & & & \\
\hline Ac. paulinae & $\mathrm{x}$ & & & & & & & & $\mathrm{x}$ & $\mathrm{x}$ & $x$ & $\mathrm{x}$ & $\mathrm{x}$ & $x$ & & $\mathrm{x}$ \\
\hline Ac. punctata & & & & & & & & & $\mathrm{x}$ & & & & $\mathrm{x}$ & & & \\
\hline Acaulospora sp. & $\mathrm{x}$ & $\mathrm{x}$ & $\mathrm{x}$ & & & & & & & & & & & & & \\
\hline \multicolumn{17}{|l|}{ Ambispora } \\
\hline Ambispora leptoticha & & & & & $\mathrm{x}$ & & & & & & & & & & & \\
\hline Ambispora sp. & & & & & & & & & $\mathrm{x}$ & & $\mathrm{x}$ & & $\mathrm{x}$ & $\mathrm{x}$ & $\mathrm{x}$ & $\mathrm{x}$ \\
\hline \multicolumn{17}{|l|}{ Archaeospora } \\
\hline Archaeospora trappei & $\mathrm{x}$ & $\mathrm{x}$ & & & $\mathrm{x}$ & $\mathrm{x}$ & $\mathrm{x}$ & $\mathrm{x}$ & $\mathrm{x}$ & & $\mathrm{x}$ & $\mathrm{x}$ & $\mathrm{x}$ & $\mathrm{x}$ & $\mathrm{x}$ & $\mathrm{x}$ \\
\hline \multicolumn{17}{|l|}{ Claroideoglomus } \\
\hline $\begin{array}{c}\text { Claroideoglomus } \\
\text { claroideum }\end{array}$ & $\mathrm{x}$ & $\mathrm{x}$ & $\mathrm{x}$ & $\mathrm{x}$ & $\mathrm{x}$ & $\mathrm{x}$ & $\mathrm{x}$ & $\mathrm{x}$ & $\mathrm{x}$ & $\mathrm{x}$ & $\mathrm{x}$ & $\mathrm{x}$ & $\mathrm{x}$ & $\mathrm{x}$ & $\mathrm{x}$ & $\mathrm{x}$ \\
\hline Cl. etunicatum & $\mathrm{x}$ & & & $\mathrm{x}$ & & & & & $\mathrm{x}$ & & $\mathrm{x}$ & & & & $\mathrm{x}$ & \\
\hline Cl. lamellosum & $\mathrm{x}$ & $\mathrm{x}$ & $x$ & $\mathrm{x}$ & & & & & & & & & & & & \\
\hline \multicolumn{17}{|l|}{ Diversispora } \\
\hline Diversispora spurca & $\mathrm{x}$ & $\mathrm{x}$ & $\mathrm{x}$ & $\mathrm{x}$ & & & & & $\mathrm{x}$ & & & & $\mathrm{x}$ & $\mathrm{x}$ & $\mathrm{x}$ & $\mathrm{x}$ \\
\hline \multicolumn{17}{|l|}{ Dominikia } \\
\hline Dominikia aurea & & & & & & & $\mathrm{x}$ & & & & & & & & & \\
\hline \multicolumn{17}{|l|}{ Funneliformis } \\
\hline Funneliformis mosseae & $\mathrm{x}$ & & & & & $\mathrm{x}$ & & & & $\mathrm{x}$ & & $\mathrm{x}$ & & & & \\
\hline
\end{tabular}




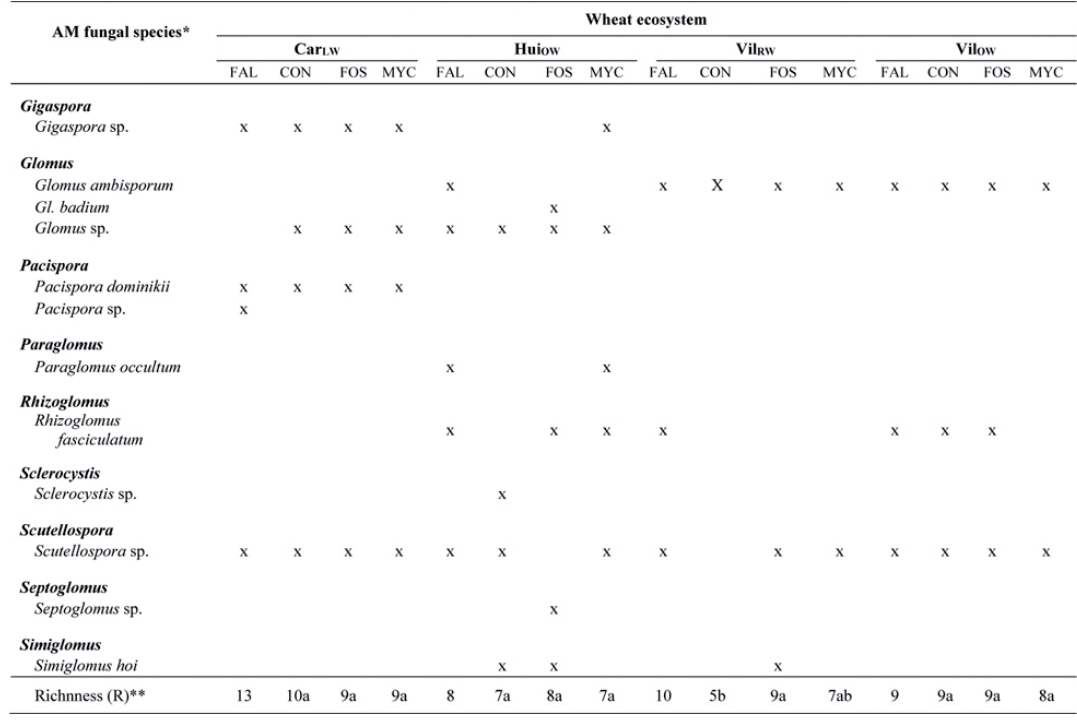

Vil $_{\text {OW: }}$ Vilcún (oats/wheat); $\mathrm{Vil}_{\mathrm{RW}}$ : Vilcún (oilseed rape/wheat); Hui ${ }_{\mathrm{OW}}$ : Huichahue (oats/wheat); $\mathrm{Car}_{\mathrm{LC}}$ : El Carmen (lupine/ wheat); FAL:fallow; CON: control; FOS: Fosfobio; MYC: Myconate. * Presence of species in any four replicates at a trial site indicated by $\mathrm{x} ; * *$ at each location values followed by different letters indicate a significant $(\mathrm{P}<0.05)$ difference

Table 3. Grain yields of wheat experiments which were established after non-mycorrhizal pre-crop lupines $\left(\mathrm{Car}_{\mathrm{LW}}\right)$ and rape $\left(\mathrm{Vil}_{\mathrm{RW}}\right)$, and after mycorrhizal pre-crop oates $\left(\mathrm{Hui}_{\mathrm{ow}}, \mathrm{Vil}_{\mathrm{ow}}\right)$. Wheat seed was either treated with fungicides/insecticides (F/I) $(\mathrm{CON})$ or treated with F/I + Fosfobio (FOS) or F/I + Myconate (MYC).

\begin{tabular}{lcccc}
\hline \multirow{2}{*}{ Location } & \multicolumn{4}{c}{ Grain yield $\left(\mathbf{k g ~ h a}^{-1}\right)$} \\
\cline { 2 - 5 } & CON & FOS & MYC & Mean \\
\hline Car & & & \\
Hui & $1600 \mathrm{a}$ & $1800 \mathrm{a}$ & $1800 \mathrm{a}$ & 1733 \\
Vil $1_{\text {RW }}$ & $2500 \mathrm{a}$ & $2400 \mathrm{a}$ & $3000 \mathrm{a}$ & 2633 \\
Vilow & $6300 \mathrm{a}$ & $5900 \mathrm{a}$ & $6800 \mathrm{a}$ & 6333 \\
Mean & $6100 \mathrm{a}$ & $5700 \mathrm{a}$ & $6100 \mathrm{a}$ & 5967 \\
\hline
\end{tabular}

Mean values within a row followed by same letters indicate non significant $(\mathrm{P}<0.05)$ difference.

\section{Discussion}

The three trials locations differed strongly in the presence or absence of AMF genera and species. While
Huichahue had higher organic matter, which could explain the differences in AM fungal genera, the other three locations were quite similar in soil characteristics. However, any relation of occurrence of specific 
AM fungal genera or species to soil characteristics is unlikely. For example, Acaulospora spp. appear to occur regularly in lower $\mathrm{pH}$ soils, as do Scutellospora spp. (Castillo et al., 2006; Oehl et al., 2006). Here however, in locations with soils of similar $\mathrm{pH}$, the presence or absence depended on the location itself. While in areas like Vilcún, where trials were next to each other, the AM fungal community was similar, other locations with different soils and crop cultivation histories had other AM fungal species compositions even though all sites were grown with wheat. This confirms findings of other researchers about site specific AM fungal communities (Oehl et al., 2005; Posada et al., 2016).

From our study of wheat agroecosystems in Southern Chile we can confirm also the presence of so-called AM fungal generalists (Oehl et al., 2003; Börstler et al., 2006), species which occur all over Southern Chile, and independent on soils and crops: such were Archaeospora trappei, Claroideoglomus claroideum and a Scutellospora sp., which was morphologically similar to S. calospora (Aguilera et al., 2014; Castillo et al., 2016b). Other species were rarely found (Table 2): Ambispora leptoticha (former A. appendicula), Dominikia aurea, Glomus badium, Paraglomus occultum, Sclerocystis sp., and Septoglomus sp. These species are known to occur in other agroecosystems of South America, and some of them are frequent like Paraglomus occultum (Sieverding, 1991) while others are not (Sieverding, 1991; Posada and Sieverding, 2014). So, its infrequent occurrence may indicate that their concentration in soils is low and not found, due do the relative small soil sample investigated, or that the relative short cropping systems did not allow completing the formation of spores in higher concentrations, like may have been the case with G. badium and Sclerocystis sp., which both form spores in sporocarps. Oehl et al. (2009) found that such sporocarpic AM fungal species need at least 9 months to complete the sporulation cycle; so, likely too short cycle for sporocarp formation under the investigated cereals cultivation in Southern Chile.

The expectation of the experiments was that the precrop would have had a significant negative effect on the diversity of AM fungi. Lupine and oilseed rape are both known as non-mycorrhizal plants, and several years continuous cropping of a non-mycorrhizal plant like rape decreased the abundance of AM fungal species although it did not eliminate them in soils of Germany (Sieverding and Oehl, 2005). However, in our experiments the sites with non-mycorrhizal precrops had even slightly higher number of AM fungi in the fallow before planting wheat (Table 2) than with the pre-crop oats, which is a mycorrhizal plant. There may have been several reasons for this: a) with non-mycorrhizal and mycorrhizal pre-crop there was a period of several months of fallow before planting wheat, during which the indigenous AM fungal population could have recovered and multiplied, b) lupine and rape are generally planted at 50-75 $\mathrm{cm}$ distance between the rows and at planting a pre-emergence herbicide is applied for weed control, which have often not long lasting efficacy. In contrast oats are planted denser and more effective post-emergence herbicides are used, which eliminate all weeds until harvest. Planting in more distance between rows and pre-emergence herbicides allow a re-establishment of weeds between rows - weed species that may have reproduced and maintained a divers plant species and divers AM fungal communities in the non-mycorrhizal crops. Oats, on the other hand had almost no weeds and only after harvest new weeds could develop. It is further well known that cereal mono-culture decrease the diversity of AM fungi (Oehl et al., 2003; Sharmah and Jha, 2014). Cultivation of wheat after non-mycorrhizal crops consequently decrease the total number of AM fungal species (Table 2), from 13 to 10 in El Carmen, and significantly from 10 to 5 species in Vil- 
cún (compare Fallow with Control); while after oats the AM fungal diversity was not strongly modified through the following cereal wheat, likely also because the AM fungal species number was lower in the pre-crop. It also may have been that the AM fungal community did not react to cultivation of wheat after oats because the AM fungal species population was adapted to cereals mono-cultivation systems, already. Such non-reaction of AM fungal population to cereals after cereals culturing is new finding and has not been reported before.

The effect of seed treatment with two natural products (FOS and MYC) did not lead to general significant changes in AM fungal species richness (Table 2), as compared to the control. The exception was Vilcún where after rape the wheat cultivation caused irregular effects on AM fungal species richness, depending on the seed treatment. However, because this occurred only at one site, we cannot make general conclusion. It appears that AM species that appeared in the Control, also regularly were found in the FOS and MYC treatments, only varying by the occurrence of some of the non-frequent AM fungal species named above. Our expectation had been that the seed treatments with natural products would increase the concentration of spores in the soil and thus consequently result in a higher AM fungal species diversity. It appears, however, that an increased initial mycorrhizal root colonization rate through seed treatment with natural products in wheat, as reported by Castillo et al. (2014), will not result in higher AM fungal species diversity. Natural products applications to cereal seeds, thus, are influencing the mycorrhizal colonization, root growth and initial growth (Castillo et al., 2014), but not the AM fungal species richness.

Grain yields of wheat at the experimental sites (Table 3) were higher in Vilcún than in the others two locations. The main reason for this may have been some differences in soil fertility as well in weather conditions and disease pressure. At El Carmen and Huichahue, no foliar fungicides had been applied and foliar diseases like those caused by Septoria spp. were not controlled, which may have dramatically affected the yields. In Vilcún, fungicides were applied to control foliar diseases. Whether the pre-crop was a non-mycorrhizal crop (lupine or rape) or a mycorrhizal crop (oats), had no consistent effect on grain yields. The effects of seed treatments by FOS and MYC on grain yields were not significant at none of the locations (Table 3). On average of four trials however, there was a tendency that MYC increased grain yields by an average of about $7 \%$ (300 kg ha $\left.{ }^{1}\right)$. FOS had no effect. MYC was reported to increase yields of crops in the range of $5-15 \%$, in the past (Westphal et al., 2008), and such increases may also be possible in wheat cultivation systems of Southern Chile. Main effect of MYC is improved root colonization by AM fungi (Baroja et al., 2010), which as consequence can lead to improved phosphate uptake (Bonfante and Anca, 2009). We had expected that the treatment with FOS would give increased yields but it may be that the inoculation of the wheat seed with $\mathrm{P}$ solubilizing bacteria is not the right technology for use of P-solubilizing bacteria. These bacteria live in the rhizosphere of roots and may even be distributed in the soil with the roots. However, P-solubilization in rhizosphere is a natural process also induced by the roots themselves, so that additional P-solubilization by bacteria is unlikely to happen in the same rhizosphere area. It is obvious that additional P, which is not normally available to plant roots can only be taken up and transported to the roots by external AM fungal mycelium, which explores regions not accessible to the roots. Even when P-solubilizing bacteria would have dissolved more $\mathrm{P}$ in distance of a few $\mathrm{mm}$ from roots, this $\mathrm{P}$ would likely not be available to plants without higher AM fungal root colonization rates, and AM fungi external mycelium. Thus, this may explain 
why, by assumed higher AM root colonization rates, MYC had tendentially positive effects on grain yield of wheat but FOS not. It can further be assumed from the results of our experiments that AM fungal species richness has little if nothing to do with yield performance of wheat. More important appears to be the actual AM root colonization which results from the indigenous AM fungal population. On the other hand, it is known that some of the members of the AM fungal community are generally quickly and extensively colonizing roots, like $\mathrm{Cl}$. claroideum, Glomus spp. and Rhizoglomus spp. It should thus be the objective of farming practices to maintain such AM fungal species in soils, which can extensively colonize roots of wheat crops in the soils of Southern Chile, which have low available $\mathrm{P}$.

\section{Conclusions}

In total $26 \mathrm{AMF}$ species were found in wheat agroecosystems of Southern Chile, which corresponds to earlier findings in the area. However, the species richness and occurrence of specific AMF species was site specific, and was unlikely related to soil characteristics. After non-mycorrhizal crops like lupine or rape the AMF species richness is not low, as had been hypothesized, and while wheat cropping after non-mycorrhizal pre-crops decreased AMF richness, wheat after oats did not change the number of AMF species. Seed treatments with the natural products investigated did not increase regularly the richness of AM fungal species in these experiments.

While wheat grain yields were not affected by seed treatments with $\mathrm{P}$-solubilizing and $\mathrm{N}$-fixing bacteria, the formononetin containing tentatively increased grain yields on average of the four trials. Because no relationship was found between wheat grain yields and AMF diversity and species richness, other factors, like increased early mycorrhizal root coloniza- tion through formononetin can have been the reason for wheat grain yield increase.

\section{Acknowledgments}

This research was supported by Fondecyt project 11090014 of the Chilean National Commission for Scientific and Technological Researc.

\section{References}

Aguilera, P, Cornejo, P, Borie, F, Barea, J.M, von Baer, E, Oehl, F. 2014. Diversity of arbuscular mycorrhizal fungi associated with Triticum aestivum L. plants growing in an Andosol with high aluminum level. Agric Ecosyst Environ. 186, 178-184.

Azcón-Aguilar, C, Barea, J.M. 2015. Nutrient cycling in the mycorrhizosphere. J .Soil Sci. Plant Nutr. 15, 372-396.

Barea, J.M. 2015. Future challenges and perspectives for applying microbial biotechnology in sustainable agricultura based on a better understanding of plant-microbiome interactions. J. Soil Sci .Plant Nutr .15, 261-282.

Baroja, L, Medina, M.E, Proaño, K. 2010. Evaluación de la actividad del formononetín, ácido 3-indol butírico y tiamina para promover la germinación in vitro de esporas de hongos micorrícico-arbusculares (HMA). Revista CIENCIA. 13(1):92-98.

Błaszkowski, J., Glomeromycota, W., Szafer. 2012. Institute of Botany Polish Academy of Sciences, Kraków.

Bonfante, P., Anca, I.A. 2009. Plants, mycorrhizal fungi, and bacteria: a network of interactions. Annu Rev Microbiol. 63, 363-383.

Borie, F., Rubio, R., Morales, A., Curaqueo, G, Cornejo. P. 2010. Arbuscular mycorrhizae in agricultural and forest ecosystems in Chile. J Soil Sci Plant Nutr. 10, 185-206. 
Börstler, B., Renker, C., Kahmen, A., Buscot, F. 2006. Species composition of arbuscular mycorrhizal fungi in two mountain meadows with differing management types and levels of plant biodiversity. Biol Fertil Soils. 42, 286-298.

Castillo, C.G., Rubio, R., Rouanet, J.L., Borie, F. 2006. Early effects of tillage and crop rotation on arbuscular mycorrhizal fungal propagules in an Ultisol. Biol Fertil Soils. 43, 83-92.

Castillo, C.G., Fredericksen, C., Koch, R., Sieverding, E. 2014. Effect of seed treatment with natural products on early arbuscular mycorrhizal colonization of wheat by Claroideoglomus claroideum. J Appl Bot Food Qual. 87, 117-123.

Castillo, C.G., Morales, D., Fuentealba, F., San Martín, V. 2016a. Colonización temprana de hongos micorrícicos arbusculares en trigo con aplicación de productos naturales en un Andisol de La Araucanía. IDESIA 34(2):63-68.

Castillo, C.G., Borie, F., Oehl, F., Sieverding, E. 2016b. Arbuscular mycorrhizal fungi biodiversity: prospecting in Southern Central Zone of Chile. A Review. J. Soil Sci Plant Nutr 16, 11-24.

Davies, F., Calderón, C., Huaman, Z., Gómez, R. 2005. Influence of a flavonoid (formononetin) on mycorrhizal activity and potato crop productivity in the highlands of Peru. Sci Hortic-Amsterdam 106, 318-329.

Harinikumar, K.M., Bagyaraj, D.J. 1988. Effect of crop rotation on native vesicular arbuscular mycorrhizal propagules in soil. Plant Soil. 110, 77-80.

Jansa, J., Mozafar, A., Kuhn, G., Anken, T., Ruh, R., Sanders, I.R., Frossard, E. 2003. Soil tillage affects the community structure of mycorrhizal fungi in maize roots. Ecol Appl. 13, 1164-1176.

Larraín, J.D., Olfos, M.J. 2013. Boletín de trigo: Producción, precios y comercio exterior. Diciembre 12 - enero 2013. ODEPA. Santiago Chile. 34p.
Miranda, J.C.C., Vilela, L., de Miranda, L.N. 2005. Dynamics and contribution of arbuscular mycorrhiza in culture systems with crop rotation. Pesqui. Agropecu. Bras. 40, 1005-1014.

Moreno, C. 2001. Métodos para medir la biodiversidad. M\&T-Manuales y Tesis SEA. Zaragoza, Spain. 84p.

Oehl, F., Sieverding, E., Ineichen, K., Mäder, P., Boller, T., Wiemken, A. 2003. Impact of land use intensity on the species diversity of arbuscular mycorrhizal fungi in agroecosystems of Central Europe. Appl. Environ. Microbiol. 69, 2816-2824.

Oehl, F., Sieverding, E., Ineichen. K., Ris, E.A., Boller, T., Wiemken, A. 2005. Community structure of arbuscular mycorrhizal fungi at different soil depths in extensively and intensively managed agroecosystems. New Phytol. 165, 273-283.

Oehl, F., Sýkorová, Z., Redecker, D., Wiemken, A., Sieverding, E. 2006. Acaulospora alpina, a new arbuscular mycorrhizal fungal species characteristic for high mountainous and alpine regions of the Swiss Alps. Mycologia. 98, 286-294.

Oehl, F., Sieverding, E., Ineichen, K., Mäder, P, Wiemken, A., Boller, T. 2009. Distinct sporulation dynamics of arbuscular mycorrhizal fungal communities from different agroecosystems in long-term microcosms. Agriculture, Ecosystems and Environment. 134, 257-268.

Pino, I., Parada, A.M., Zapata, F., Navia, M., Luzio, W. 2002. Comparative study of P uptake and utilization from $P$ fertilizers by Chilean wheat genotypes in volcanic ash soils. In: Assessment of Soil Phosphorus Status and Management of Phosphatic Fertilisers to Optimise Crop Production. International Atomic Energy Agency, IAEA-TECDOC-1272. pp. 156-163. Vienna.

Posada, R.H., Sieverding, E. 2014. Arbuscular mycorrhiza in Colombian coffee plantations fertilized with coffee pulps as organic manure. J. Appl. Bot./Angewandte Botanik. 87, 243-248. 
Posada, R.H., Sánchez, de Prager. M., Heredia-Abarca, G., Sieverding, E. 2016. Effects of soil physical and chemical parameters, and farm management practices on arbuscular mycorrhizal fungi communities and diversities in coffee plantations in Colombia and Mexico. Agroforest Syst. DOI 10.1007/s10457-016-0030-0.

Sarabia-Ochoa, M., Madrigal-Pedraza, R., Martínez-Trujillo, M., Carreón Abud, Y. 2010. Plantas, hongos micorrízicos y bacterias: su compleja red de interacciones. Biológicas. 12, 65-71.

Schenck, N.C, Pérez, Y. 1990. Manual for the Identification of VA Mycorrhizal Fungi. Synergistic Publications, Gainesville, Florida, USA.

Sharmah, D., Jha, D.K. 2014. Diversity of arbuscular mycorrhizal fungi in disturbed and undisturbed forests of Karbi Anglong Hills of Assam, India. Agric Res. 3, 229-238.

Sieverding. E. 1991. Vesicular-arbuscular Mycorrhiza Management in Tropical Agrosystems. Deustche Gesellschaft für Technische Zusammenarbeit (GTZ) N²24. Eschborn, Germany. 371p.

Sieverding, E., Oehl, F. 2005. Are arbuscular mycorrhizal fungal species invasive-derived from our knowledge about their distribution in different ecosystems?. BCPC Symposium Proc 81, 197202.
Siqueira, J.O., Lambais, M.R., Sturmer, S.L. 2002. Fungos micorrízicos arbusculares: características, associação simbiótica e aplicação na agricultura. Biotecnologia Ciência e Desenvolvimento. 25, 12-21.

Siqueira. J.O., Safir, G.R., Nair, M.G. 1991. Stimulation of vesicular arbuscular mycorrhiza formation and growth of white clover by flavonoid compounds. New Phytol. 118, 87-93.

Soka. G., Ritchie, M. 2015. Arbuscular mycorrhizal symbiosis, ecosystem processes and environmental changes in tropical soils. Appl. Ecol. Environ. Res. 13, 229-245.

Westphal, A, Snyder, N., Xing, L. 2008. Effects of inoculations with mycorrhizal fungi of soilless potting mixes during transplant production on watermelon growth and early fruit yield. HortScience. 43, 354-360.

Zagal, E., Sadzawka, A. 2007. Protocolo de métodos de análisis para suelos y lodos. Universidad de Concepción. Facultad de Agronomía. Chillán. Chile. 